Check for updates

The BMJ

Cite this as: $B M J 2020 ; 370: m 2805$ http://dx.doi.org/10.1136/bmj.m2805 Published: 10 July 2020

\section{Covid-19: Government is criticised for "scandalous" f10bn spent on test and trace programme}

\author{
Gareth lacobucci
}

The UK government has spent €1obn ( $€ 11.2 \mathrm{bn} ; \$ 12.7 \mathrm{bn})$ on its much derided covid-19 test and trace programme and $£ 15 \mathrm{bn}$ on personal protective equipment for frontline healthcare staff, the Treasury disclosed this week.

It revealed the figures in a document summarising the substantial financial commitments made by the government in response to covid-19, ${ }^{1}$ published on 8 July as part of the chancellor's plan for jobs. The Treasury also disclosed that, since mid-March, the government had spent £1bn on additional ventilators for the NHS and $€ 5.5 \mathrm{bn}$ on other health spending, such as paying for extra capacity in private sector facilities.

Experts said that they were astonished at the size of the sums, including the billions paid to private companies such as Serco to run "test and trace" services.

\section{Private companies}

Allyson Pollock, co-director of the Newcastle University Centre for Excellence in Regulatory Science and a member of the Independent Scientific Advisory Group for Emergencies, described the £1obn figure as "scandalous expenditure."

She added, "There are really serious questions to be asked about the way these contracts were set up and about their performance. Ten billion pounds spent, and we don't even have an effective test and trace strategy. Not all cases are being detected, half of cases are not giving contacts, and those which do are largely doing it through traditional public health teams, while the commercial call handlers have got little to do.

"This money should have been put into supporting the established system of public health services instead of going into new parallel centralised services run by private companies, where much of it is squandered and wasted."

Chris Ham, former chief executive of the King's Fund, said that the numbers were "astonishing." He tweeted: "Would be good to understand exactly what money was spent on, especially on test and trace where expertise in NHS and local authorities has been overlooked as private sector used."2

Rachel Reeves, Labour's shadow cabinet office minister, called for a full published breakdown of the £1obn. She added, "Early in the crisis the government wasted the opportunity to build on existing expertise and experience within our public services for contact tracing, and instead ministers chose to hand lucrative contracts to a handful of outsourcing companies including some with a questionable record of delivery."

Commenting on the £1obn spent on testing and tracing, a Department of Health and Social Care spokesperson said, "NHS Test and Trace is a new, large scale service, designed to allow us to return to as near to normal as possible, so that we can rebuild the economy, control the virus, and save lives.

"Using this funding we have established one of the world's largest testing programmes from scratch, which has already delivered over 11 million tests across the whole UK, employed 27000 contact tracers who have already contacted tens of thousands people, and furthered our ongoing work to contain the virus-including setting up the Joint Bio-Security Centre.”

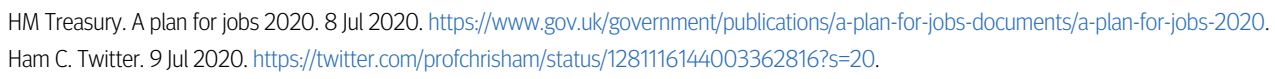

This article is made freely available for use in accordance with BMJ's website terms and conditions for the duration of the covid-19 pandemic or until otherwise determined by BMJ. You may use, download and print the article for any lawful, non-commercial purpose (including text and data mining) provided that all copyright notices and trade marks are retained. 